\title{
Work ability in hospital housekeeping services and associated factors
}

\author{
Capacidade para o trabalho no serviço \\ hospitalar de limpeza e fatores associados \\ Capacidad para trabajar en servicio de \\ limpieza hospitalaria y los factores asociados \\ Marlize Tatsch Beltrame \\ Tânia Solange Bosi de Souza Magnago ${ }^{b}$ \\ Ana Lúcia Cardoso Kirchhof \\ Cintia da Silva Marconato ${ }^{d}$ \\ Bruna Xavier Morais ${ }^{\mathrm{e}}$
}

D0l: $\quad$ http://dx.doi.org/10.1590/19831447.2014.04.50715

\section{ABSTRACT}

This study aimed to measure the Work Ability Index of workers of a hospital housekeeping staff and identify the associated factors. Cross-sectional study conducted in 201 with 157 workers of the housekeeping staff of a university hospital in Rio Grande do Sul, Brazil. A questionnaire containing sociodemographic, labor and health variables and the Brazilian version of the Work Ability Index was used. As a result, $79.6 \%$ of the workers were classified as having good/great work capacity. Mild mental (31.8\%) and musculoskeletal disorders (15.9\%) were the most prevalent medical diagnoses. After some adjustments, the workers that did not have time for leisure showed a 2.67 times higher prevalence of having the work ability reduced ( $(195 \%=1.23-5.82)$. The other variables lost their association with the outcome. Measures aimed at the maintenance of work ability and the practice of physical activity and training for postural care are indicated.

Descriptors: Nursing. Occupational health. Housekeeping, hospital. Work capacity evaluation.

\section{RESUMO}

Objetivou-se mensurar o índice de capacidade para o trabalho em trabalhadores do Serviço Hospitalar de Limpeza e identificar os fatores a ele associados. Estudo transversal realizado em 2013, com 157 trabalhadores do serviço de limpeza de um hospital universitário público do Rio Grande do Sul, Brasil. Utilizou-se um formulário contendo variáveis sociodemográficas, laborais, de saúde e a versão brasileira do Índice de Capacidade para o Trabalho. Como resultado, 79,6\% dos trabalhadores foram classificados com boa/ ótima capacidade para 0 trabalho. Os distúrbios mentais leves $(31,8 \%$ ) e os musculoesqueléticos $(15,9 \%)$ foram os diagnósticos médicos mais prevalentes. Após ajustes, os trabalhadores que não possuíam tempo para o lazer apresentaram uma prevalência 2,67 vezes mais elevada de ter a capacidade para 0 trabalho reduzida (IC95\%=1,23-5,82). As demais variáveis perderam a associação. Indicam-se medidas de manutenção da capacidade laboral, como a prática de atividade física e capacitação para cuidado postural.

Descritores: Enfermagem. Saúde do trabalhador. Serviço hospitalar de limpeza. Avaliação da capacidade de trabalho.

\section{RESUMEN}

Se objetivó medir el porcentaje de la capacidad para el trabajo en trabajadores del servicio de limpieza hospitalaria e identificar los factores asociados a ella. Estudio transversal realizado en 2013, con 157 trabajadores de un hospital universitario de Rio Grande do Sul, Brasil. Se utilizó un cuestionario con variables sociodemográficas, laborales y de salud y la versión brasilera del Índice de Capacidad para el Trabajo. Como resultado, el 79,6\% de los trabajadores fue clasificado como bueno/gran capacidad de trabajo. Trastornos mentales leves (31,8\%) y musculoesquelético (15,9\%) fueron los diagnósticos médicos más frecuentes. Después de los ajustes, los trabajadores que no tuvieron tiempo para ocio tenían un 2,67 veces mayor prevalencia reducir la capacidad de trabajar (IC95\%=1,235,82). Las otras variables pierden su asociación. Se indican medidas de manutención de la capacidad laboral y práctica de actividad física y capacitación para el cuidado postural.

Descriptores: Enfermería. Salud laboral. Servicio de limpieza en hospital. Evaluación de capacidad de trabajo. 


\section{DINTRODUCTION}

Hospital Housekeeping Services (HHS) is essential in health institutions. The workers of the cleaning staff of a hospital are responsible for the organization of the environment, cleaning of equipment and facilities, contributing to reduce the risk of infection and promoting patient safety ${ }^{(1)}$.

In the hospital setting, the workers of a hospital housekeeping staff are usually outsourced. There are many references in the literature to the fact that these workers, outsourced ${ }^{(2)}$ or not ${ }^{(3)}$, enter the labor market early, have low level of education and are underpaid. These workers develop sanitizing and cleaning activities, through the use of mechanical and chemical processes ${ }^{(1)}$. A remarkable feature of this work is the muscular effort required to lift and transport weights, perform repetitive movements and in tilting movements of the body. Also, the referred workers are exposed to chemicals and workplace accidents. These daily exposures may damage health ${ }^{(4)}$ and the ability to develop their work activities ${ }^{(5)}$.

Work ability is directly related to the possibility of performing activities that involve physical, mental and functional aptitudes ${ }^{(5)}$. It is defined as "how well a worker is now, or will be in the near future, and how capable he or she is to perform his or her work, depending on their requirements, health status and physical and mental conditions ${ }^{\prime \prime(5)}$. The measurement is made by the Work Ability Index (WAI), which comprises individual and labor aspects.

The determination of the WAI is based on the answers to a series of questions, considering the physical and mental requirements of the work, the health status and the resources used by the worker. The results of this assessment can support the development of health care programs ${ }^{(5)}$. Since this population is usually under the direct or indirect management of nurses, these should be responsible for such assessment.

To support this study, we carried out a systematic search at LILACS database using descriptors "Work Capacity Evaluation" AND "Occupational Health", and 21 articles were identified. After a critical reading of the abstracts, it was found that none of them involved workers of a hospital housekeeping staff. In another search at this database using the descriptor "Hospital housekeeping", 51 studies were found. Of these, one assessed WAl(3), and showed that it was low in $14.5 \%$ of the workers aged 50 to 60 years and in those affected by a greater number of diseases. The search at PubMed, using the strategy "Work Capacity Evaluation" AND "Housekeeping, Hospital", led to the same study (3).

Therefore, in view of the individual and labor characteristics and the early labor market entry of this population, as well as the predictive value of the work ability index, (WAI) the present study consists in a dissertation ${ }^{(6)}$ with the following research questions: How is the work capacity of professionals of the housekeeping staff of a university hospital of Rio Grande do Sul? What are the factors associated to this capacity? It is believed that the diagnosis discussed here may contribute to the development of health promotion programs for this population.

Thus, we aimed to measure the work ability index in workers of the housekeeping staff of a hospital and identify the related factors.

\section{口ETHOD}

Cross-sectional study approved by the Research Ethics Committee of the institution, under CAAE 13106313. 1.0000.5346, on February 26, 2013, in a public university hospital of Rio Grande do Sul, Brazil. The workers of the housekeeping staff are distributed as follows: in teams of cleaning workers (maintenance cleaning and terminal disinfection in all sectors) and cleaning helpers for cleaning materials (equipment and instruments).

The study population was composed of the total number of workers ( $N=161)$. Two (1.2\%) were excluded because they were on sick leave. Of the eligible population (159), 157 completed the questionnaire (98.7\%). The losses (1.3\%) resulted from refusals.

Data collection was performed between March and April 2013 by a team of previously trained graduate students, postgraduate students and nurses. The worker was invited to participate in the study and after agreement, signed the Free Informed Consent, according to Resolution 466/12. The participants answered the questionnaire in the workplace during their shift (morning, afternoon or evening), in a separate room. Given the literature ${ }^{(3)}$ evidence on the low level of education of this group of workers, the interviewer read the questions and the response options, ticking the response issued by the respondent. Thus, for quality control purposes, the worker also had a form (questionnaire) to follow the reading of the questions and visualize the possible response options before issuing them.

The collection form had two parts. Part 1, developed by the researchers, consisted of the independent variables: a) sociodemographic (age, gender, education, skin color/ race, marital status, children and income), b) labor (function, work sector, length of time working in the function/ sector, shift, weekly workload, another job), c) health (medical, psychological treatment, use of tobacco, alcohol, medicines, sleep, leisure, Body Mass Index) $)^{(7)}$. 
The Part 2 of the form was the Brazilian version of the WAI(5) (dependent variable), developed by a group of researchers of the Finnish Institute of Occupational Health, in 1997. The WAI consists of seven items that comprise: current ability to meet work requirements, diagnosed diseases, estimated number of times the worker has been absent because of sickness, absence from work due to sickness in the past year, own prognosis of work ability and mental resources used (enjoy daily activities, feel alive and alert, have hopes for the future) $)^{(5)}$.

The database was organized with the Epi-info ${ }^{\oplus}$ software, using double data entry. After correction of errors and inconsistencies, analysis was carried out with the PASW Statistics ${ }^{\circledast}$ (Predictive Analytics Software). Descriptive statistics (measures of position and dispersion, according to normal or non-normal data distribution) was used in the analysis of continuous variables. The categorical variables were assessed in absolute and relative frequencies.

The WAI score was constructed by summing the points assigned to each one of the seven items, according to the instructions in the manual ${ }^{(5)}$. The score ranged from 7 to 49 points, as follows: 7 to 27 (low), 28 to 36 (moderate), 37 to 43 (good) and 44 to 49 (excellent work ability). For bivariate and multivariate analyzes, the categories Low, Moderate, Good and excellent ability were dichotomized into Low/ moderate (07 to 36) and Good/excellent work ability (37 to 49 ).

For multivariate analysis, Poisson Regression model was used, being expressed by the Prevalence Ratio (PR) and its respective confidence intervals (C195\%). All the variables associated to the outcome at a significance level of 0.25 were considered confounding variables in the crude and adjusted models. In all the analyzes, the association was considered statistically significant when $p \leq 0.05$.

Assessment of the internal consistency of the WAl, measured by measured by Cronbach's alpha coefficient, showed a satisfactory consistency of the instrument $(a=$ 0.73). Kolmogorov-Smirnov test was used to assess data adherence to normal distribution.

\section{QRESULTS}

Most workers were women (87.9\%), with average age of 39.9 years ( \pm 9.8$)$, minimum 19 and maximum 60 years, who declared themselves to be white (63.7\%); married and/or living with a partner (64.3\%), having one child (28.0\%); have completed secondary education (38.9\%) and average household income per head of less than one national minimum wage (mean $0.86( \pm 0,47)$; minimum 0.20 and maximum 2.95 wages).
It was found that most Cleaning Workers (65.6\%) have been working in the institution in average for 32.5 months $( \pm 48,9)$ and in the sector for 24.5 months $( \pm 39.7)$. The percentage of cleaning workers who performed their activities in the day shift was (80.9\%); (72.6\%) reported that the number of workers in the working timetable was adequate and (65.9\%) were satisfied with their pay. A higher percentage $(88,5 \%)$ reported not having another job, $(67.7 \%)$ did not work overtime and (72\%) did not receive in-house training.

The next data concern health variables: (50.3\%) cleaning workers have never smoked I (89.2\%) did not drink alcohol and $(98,7 \%)$ did not take drugs. In the last 12 months prior to the study, $58.6 \%$ required medical care and $6.4 \%$, needed psychological care. Of these, $51 \%$ were taking medicines. The average hours of sleep per day were 7.1 hours $( \pm 1.6)$ and $59.2 \%$ reported having time for leisure activities. Regarding the analysis of the Body Mass Index (BMI), 1.9\% were underweight, $27.4 \%$ had normal weight and $70.7 \%$ had increased body weight, distributed as follows: $36.9 \%$ pre-obese and $33.8 \%$ with obesity grades I, II and III.

When each question of the WAI was separately analyzed, the following results were obtained according to the responses of the participants. Asked about their current work ability level, considering a 0-10 scale, with zero indicating inability to work and 10 the best degree of capacity, $36.6 \%$ rated themselves at the highest level (10). The average value in this item was $8.61( \pm 1.57)$, minimum zero and maximum 10.

Concerning the current work ability considering the physical and mental requirements, respectively $44.4 \%$ and $63.5 \%$ of these workers rated it as good. A small percentage of workers rated their current ability to work as low regarding the physical (6.3\%) and mental (3.2\%) requirements.

Of those who became sick, the average number of diseases diagnosed by the physician was $2.24( \pm 2.67)$, ranging from one to 15 diseases. Mild mental disorders (31.8\%) and musculoskeletal disorders (15.9\%) were the most prevalent medical diagnoses.

Regarding satisfaction with daily activities, (30.3\%) replied that they were almost always satisfied; $54.8 \%$, were always satisfied; $11.6 \%$, sometimes; and $2.6 \%$, rarely. Regarding feeling active and alert, for $28.4 \%$, this occurred almost always; for $64.5 \%$, always; for $6.5 \%$, sometimes; and for $0.6 \%$, rarely. Regarding the item feeling hope for the future, $71 \%$ of the workers replied that they felt continually hopeful ; 18.7\%, almost always; 7,7\%, sometimes; and $2.6 \%$ of them rarely felt hope for the future.

The general scoring of the WAI ranged from 20 to 49 points, with an average of $40.7( \pm 5.6)$ and median of 42 points. Six (3.8\%) workers were classified as having low abil- 
Table 1. Distribution of workers of the hospital housekeeping staff of the hospital, according to the questions of the Work Ability Index. Santa Maria/RS, Brazil, 2013 (N=157).

Questions

\section{Number of current diseases diagnosed by a physician}

$\begin{array}{lcc}\text { None } & 47 & 29.9 \\ 01 & 38 & 24.2 \\ 02 & 22 & 14.0 \\ 03 & 22 & 10.8 \\ 04 & 17 & 3.2 \\ 05 \text { or more } & 5 & 28 \\ \end{array}$

\section{Estimated number of times the worker has been absent because of sickness (self-perception)}

I am totally unable to work

I am able to work only part-time

I often need to slow the pace of work or change work methods

I sometimes need to slow the pace of work or change work methods

Able to do the work, but it causes some symptoms

There is no impediment / No diseases

$37 \quad 23.6$

\section{Absence from work due to sickness in the past year (days)}

$\begin{array}{lcc}100 \text { to } 365 & 2 & 1.3 \\ 25 \text { to } 99 & 6 & 3.8 \\ 10 \text { to } 24 & 10 & 6.4 \\ \text { Up to } 9 & 50 & 31.8 \\ \text { None } & 89 & 56.7\end{array}$

Own prognosis of work ability two years from now

$\begin{array}{lcc}\text { It is unlikely } & 7 & 4.5 \\ \text { Not very sure } & 28 & 17.8 \\ \text { Very likely } & 122 & 77.7\end{array}$

Source: Research data.

ity; 25 (16.6\%), with moderate ability; 69 (43.9\%), with good ability; and 56 (35.7\%), with excellent work ability. When the categories were dichotomized, 32 (20.4\%) had low/ moderate ability and 125 (79.6\%), good/excellent ability.

None of the sociodemographic variables was associated to work ability $(p>0.05)$.

Most (96.7\%) workers of the night shift obtained a significant classification of good/excellent for work.

Workers classified in the good/excellent category: $88.2 \%$ of those who had time for leisure, $87.7 \%$ of those who did not require medical care and $81.6 \%$ of those who did not need psychological care.

After the adjustments, the workers who did not have time for leisure showed a 2.67 times higher prevalence of having the work ability reduced. The other variables lost association.

\section{DISCUSSION}

The sociodemographic and economic characteristics of workers of a hospital housekeeping staff identified here corroborate the results of other studies ${ }^{(3,8)}$, except for age that showed the lowest mean ${ }^{(8-9)}$. The profile identified in this study is consistent with the profile of a group of workers that perform less paid jobs that do not require professional qualification (2).

The internal consistency of the WAI was satisfactory, corroborating the values obtained in other studies with ad- 
Table 2. Distribution of workers of a hospital housekeeping staff, according to the Work Ability Index and sociodemographic variables. Santa Maria/RS, Brazil, 2013.

\begin{tabular}{|c|c|c|c|c|c|}
\hline \multirow{3}{*}{ Variables } & \multicolumn{4}{|c|}{ Work ability } & \multirow{3}{*}{$\mathbf{p}$} \\
\hline & \multicolumn{2}{|c|}{ Low/moderate } & \multicolumn{2}{|c|}{ Good/excellent } & \\
\hline & $\mathbf{N}$ & $\%$ & $\mathbf{N}$ & $\%$ & \\
\hline Sex & & & & & 0.207 \\
\hline Male & 2 & 10.5 & 17 & 89.5 & \\
\hline Female & 30 & 21.7 & 108 & 78.3 & \\
\hline Age & & & & & 0.488 \\
\hline 19 to 34 years & 8 & 15.7 & 43 & 84.3 & \\
\hline 35 to 44 years & 10 & 20.0 & 40 & 80.0 & \\
\hline 45 to 60 years & 14 & 25.0 & 42 & 75.0 & \\
\hline Education & & & & & 0.315 \\
\hline Graduate & 32 & 21,1 & 120 & 78.9 & \\
\hline Non-graduate & 0 & 0 & 5 & 100.0 & \\
\hline Self-declared race/color & & & & & 0.569 \\
\hline White & 19 & 19.0 & 81 & 81.0 & \\
\hline Other & 13 & 22.8 & 44 & 77.2 & \\
\hline Marital status & & & & & 0.068 \\
\hline Married/living with a partner & 25 & 24.8 & 76 & 75.2 & \\
\hline Single/ without a partner & 7 & 12.5 & 49 & 87.5 & \\
\hline Number of children & & & & & 0.184 \\
\hline None & 3 & 14.3 & 18 & 85.7 & \\
\hline Up to 03 & 23 & 20.2 & 91 & 79.8 & \\
\hline More than 03 & 6 & 27.3 & 16 & 72.7 & \\
\hline Household income per head capita familiar ( $N=156)$ & & & & & 0.637 \\
\hline$<1$ minimum wage & 20 & 19.4 & 83 & 80.6 & \\
\hline 1 to 2 minimum wages & 12 & 22.6 & 41 & 77.4 & \\
\hline
\end{tabular}

Source: Research data.

ministrative workers. ${ }^{(10)}(a=0.73)$ and electric utility workers (11) $(a=0.72)$, though lower than the value obtained for nursing workers $(a=0.90)^{(12)}$.

Regarding the current work ability level, unlike this study, workers of the housekeeping staff of a university hospital in Paraná (Hospital Universitário do Norte do Paraná) showed a lower percentage with score 10 and higher percentage with score 8 (30.6\% vs $22.3 \%$ ), indications of excellent work ability ${ }^{(8)}$. These percentages for the highest scores of the WAU can be related to the selection process. Since it is a selection process, there is a greater possibility of hiring workers more able to perform their activities and, thus, with a higher score in this item ${ }^{(10)}$.
Concerning the current work ability considering the physical and mental requirements, the workers rated it as good, but had more favorable outcomes in the mental requirements than in the physical requirements. The work performed by workers of a hospital housekeeping staff is predominantly physical, and there is greater reduction in work ability when health impairment occurs as a result of physical labor ${ }^{(5)}$.

Regarding the physical demands in hospital housekeeping, the hospital setting requires several types of cleaning, depending on the process used and the site to be cleaned, e.g. concurrent cleaning (daily cleaning and replacement of materials), the cleaning of floors and walk- 
Table 3. Distribution of workers of a hospital housekeeping staff, according to the Work Ability Index and labor variables. Santa Maria/RS, 2013.

\begin{tabular}{|c|c|c|c|c|c|}
\hline \multirow{3}{*}{ Variables } & \multicolumn{4}{|c|}{ Work ability } & \multirow{3}{*}{$\mathbf{P}$} \\
\hline & \multicolumn{2}{|c|}{ Low/moderate } & \multicolumn{2}{|c|}{ Good/excellent } & \\
\hline & $\mathbf{N}$ & $\%$ & $\mathbf{N}$ & $\%$ & \\
\hline Function & & & & & 0.998 \\
\hline Cleaning worker & 21 & 20.4 & 82 & 79.6 & \\
\hline Helper (cleaning of materials) & 11 & 20.4 & 43 & 79.6 & \\
\hline Work shift & & & & & 0.010 \\
\hline Day & 31 & 24.4 & 96 & 75.6 & \\
\hline Night & 1 & 3.3 & 29 & 96.7 & \\
\hline Working timetable & & & & & 0.772 \\
\hline Sufficient & 23 & 19.8 & 93 & 80.2 & \\
\hline Insufficient & 9 & 22.0 & 32 & 78.0 & \\
\hline Another job & & & & & 0.291 \\
\hline No & 27 & 19.4 & 112 & 80.6 & \\
\hline Yes & 5 & 27.8 & 13 & 72.2 & \\
\hline Overtime & & & & & 0.497 \\
\hline No & 20 & 18.9 & 86 & 81.1 & \\
\hline Yes & 12 & 23.5 & 39 & 76.5 & \\
\hline In-house training & & & & & 0.224 \\
\hline No & 6 & 28.6 & 15 & 71.4 & \\
\hline Sometimes & 9 & 39.1 & 14 & 60.9 & \\
\hline Yes & 17 & 15.0 & 96 & 85.0 & \\
\hline
\end{tabular}

Source: Research data.

ways and terminal cleaning (floors, walls and attachments) (13). In any of these types of cleaning, the physical requirements (weight lifting and loading, execution of repetitive motions, overloading of the joints, body posture, etc.) are part of the everyday work of a hospital housekeeping staff. This dynamics corroborates the reports on the musculoskeletal diseases described. Among them, back pain radiating down the back of the leg (sciatic) obtained the highest percentage of medical diagnoses (13.4\%), and pain in the lower back was the most self-declared condition (26.1\%). A review corroborates the findings, demonstrating that musculoskeletal disorders were associated with physical stressors (inadequate postures and prolonged standing) and to psychosocial stressors (monotonous work, low potential for promotion) $)^{(4)}$.

However, the workers that participated in the study showed a profile favorable to their health, since when asked whether their disease/lesion was an obstacle to their current job, $56.1 \%$ reported they did not have such impediment. Health has a direct and positive implication in work ability, so that the healthier the employee is, the greater his/her ability ${ }^{(5)}$. The investigation of workers of a hospital housekeeping staff in the state of Paraná corroborates this evidence, since $88.9 \%$ of the workers who had not been absent from work showed a good/excellent WAl(8).

In this study, despite the favorable profile, it should be taken into consideration that $43.3 \%$ of the workers had absences from work. Of this percentage, 31.8\% for up to nine days, which is similar to the findings of the hospital in Paraná $(38 \%)^{(8)}$. Another study developed in a public hospital showed high rates of absenteeism and occupational hazards in this population ${ }^{(13)}$. Regarding absenteeism, it is important to stress that outsourced workers do not have job security, which could inhibit absence from work, even in the presence of symptom of any disease. 
Table 4. Distribution of workers of a hospital housekeeping staff, according to the Work Ability Index and health-related variables/RS, Brasil, 2013.

\begin{tabular}{|c|c|c|c|c|c|}
\hline \multirow{3}{*}{ Variables } & \multicolumn{4}{|c|}{ Work ability } & \multirow{3}{*}{$\mathbf{P}$} \\
\hline & \multicolumn{2}{|c|}{ Low/moderate } & \multicolumn{2}{|c|}{ Good/excellent } & \\
\hline & $\mathbf{N}$ & $\%$ & $\mathbf{N}$ & $\%$ & \\
\hline Time for leisure & & & & & 0.001 \\
\hline No & 8 & 47.1 & 9 & 52.9 & \\
\hline Sometimes & 13 & 27.7 & 34 & 72.3 & \\
\hline Yes & 11 & 11.8 & 82 & 88.2 & \\
\hline Use of tobacco & & & & & 0.732 \\
\hline No & 15 & 19.0 & 64 & 81.0 & \\
\hline Yes & 10 & 19.6 & 41 & 80.4 & \\
\hline I quit smoking & 7 & 25.9 & 20 & 74.1 & \\
\hline Suspicion of alcoholism (CAGE*) & & & & & 0.404 \\
\hline No & 2 & 18.2 & 9 & 81.8 & \\
\hline Yes & 0 & 0 & 6 & 100.0 & \\
\hline Use of medicines & & & & & 0.286 \\
\hline No & 13 & 16.9 & 64 & 83.1 & \\
\hline Yes & 19 & 23.8 & 61 & 76.3 & \\
\hline Medical care during the past year & & & & & 0.035 \\
\hline No & 8 & 12,3 & 57 & 87.7 & \\
\hline Yes & 24 & 26.1 & 68 & 73.9 & \\
\hline Psychological care & & & & & 0.031 \\
\hline No & 27 & 18.4 & 120 & 81.6 & \\
\hline Yes & 5 & 50.0 & 5 & 50.0 & \\
\hline Has suffered at work & & & & & 0.714 \\
\hline No & 27 & 20.9 & 102 & 79.1 & \\
\hline Yes & 5 & 17.9 & 23 & 82.1 & \\
\hline Body Mass Index & & & & & 0.616 \\
\hline Normal & 20 & 19.2 & 84 & 80.8 & \\
\hline Overweight/obese & 12 & 22.6 & 41 & 77.4 & \\
\hline
\end{tabular}

Source: Research data.

* CAGE questionnaire (acronym that refers to the four questions - Cut down, Annoyed by criticism, Guilty e Eye-opener).

Regarding satisfaction, most workers said they were satisfied with their daily activities, felt active, alert and had hopes for the future. The authors noted that only a minority of the workers exposed their job dissatisfaction, which may be underestimated ${ }^{10)}$. A study suggests that, despite these workers, just like health professionals, experience a high level of distress (coexistence and daily confrontation with the suffering of patients), the awareness that their activities reduce the risk of infection and promote the safety of patients ${ }^{(1)}$ is a cause of satisfaction for them, even when they know that what they do is poorly recognized by many people ${ }^{(13)}$. This satisfaction can contribute to the maintenance of high levels of WAl.

Therefore, a small percentage of workers was classified as having low work ability. The percentages demonstrated here are similar to those obtained in other studies that found $15.2 \%$ and $25.2 \%$ for low/moderate ability and $69.4 \%$ to $84.8 \%$ for good/excellent ability ${ }^{(8,10)}$. However, they differ 
nance actions are indicated for this group. However, 20.4\% showed low/moderate ability. This group needs immediate actions aimed to restore and improve their work ability. Of the assessed factors, only lack of leisure time was significantly associated to reduce work ability.

Institutional measures aimed to maintain, restore and improve work ability are recommended for both groups, as follows: elaboration of a program of physical activity with stretching and aerobic exercises and walking; training for postural self-care with the promotion of activities to minimize the discomforts and the potential risk of injury resulting from improper body positions during work activities.

The challenge for the nurse manager or the member of the worker health team is to intervene in the reality of occupational diseases of this population. The use of the WAI as a health indicator may help them in this task.

Although this study involved all the workers of the institution, the size of the assessed population is one limitation of the study, as well as the fact that all the participants worked in the same institution. We suggest follow-up studies in further investigations, where institutions with different processes of selection/admission are chosen, to evaluate the associations that were not identified in the present study.

Acknowledgment: To CNPq, for the Edital Universal 2013, Processo no.481096/2013-2 and to UFSM, for the PROIC/HUSM

\section{REFERENCES}

1. Ministeŕrio da Saúde (BR), Agência Nacional de Vigilância Sanitária. Segurança do paciente em serviç̧os de saúde: limpeza e desinfecção de superfícies. Braślila (DF);2010.

\section{Author's address:}

Tânia Solange Bosi de Souza Magnago

Av. Roraima, 1000, prédio 26, Centro de Ciências da

Saúde, Universidade Federal de Santa Maria

97105-900, Santa Maria, RS

E-mail: tmagnago@terra.com.br
2. Chillida MSP, Cocco MIM. Saúde do trabalhador \& terceirização: perfil de trabalhadores de serviço de limpeza hospitalar. Rev Latino-Am Enferm. 2004;12(2):271-6.

3. Andrade $(B$, Monteiro MI. Envelhecimento e capacidade para o trabalho dos trabalhadores de higiene e limpeza hospitalar. Rev Esc Enferm USP. 2007;41(2):237-44.

4. Charles LE, Loomis D, Demissie Z. Occupational hazards experienced by cleaning workers and janitors: a review of the epidemiologic literature. Work. 2009;34(1):105-16.

5. Tuomi K, IImarinen J, Jahkola A, Katajarinne L, Tulkki A. Índice de capacidade para 0 trabalho. Fischer FM, tradutor. São Carlos: EdUFSCAR; 2005.

6. Beltrame M. Hábitos saudáveis e capacidade para o trabalho em trabalhadores do serviço hospitalar de limpeza [dissertação]. Santa Maria (RS): Programa de Pós-Graduação em Enfermagem, Universidade Federal de Santa Maria; 2014.

7. Ministério da Saúde (BR), Secretaria de Atenção à Saúde. Departamento de Atenção Básica. Orientações para a coleta e análise de dados antropométricos em serviços de saúde: norma técnica do Sistema de Vigilância Alimentar e Nutricional - SISVAN. Brasília (DF); 2011.

8. Silva LG, Haddad MCL, Domansky RC, Vituri DW. Capacidade para o trabalho entre trabalhadores de higiene e limpeza de um hospital universitário público. Rev Eletr Enf. 2010;12(1):158-63.

9. Martarello NA, Benatti MC. Qualidade de vida e sintomas osteomusculares em trabalhadores de higiene e limpeza hospitalar. Rev Esc Enferm USP. 2009; $43(2): 422-8$.

10. Martinez MC, Latorre MRDO. Saúde e capacidade para o trabalho em trabalhadores de área administrativa. Rev Saúde Pública. 2006;40(5):851-8.

11. Martinez MC, Latorre MRD0, Fischer M. Validade e confiabilidade da versão brasileira do Índice de Capacidade para o Trabalho. Rev Saúde Pública. 2009; 40(3):525-32.

12. Fischer FM, Borges NS, Rotenberg L, Latorre MRDO, Soares NS, Rosa PLFS, et al. A (in)capacidade para o trabalho em trabalhadores de enfermagem. Rev Bras Med Trab. 2005;3(2):97-103.

13. Sznelwar LI, Lancman S, Wu MJ, Alvarinho E, Maria S. Análise do trabalho e serviço de limpeza hospitalar: contribuições da ergonomia e da psicodinâmica do trabalho. Rev Produção. 2004;14(3):45-57.

14. Lopes JA, Longo GZ, Peres KG, Boing AF, Arruda MP. Fatores associados à atividade física insuficiente em adultos: estudo de base populacional no sul do Brasil. Rev Bras Epidemiol. 2010;13(4):689-98.

Received: 07.10.2014

Approved: 29.10.2014 